\title{
Measuring intellectual capital and ways to make organizational change: A case study of Maxwell model
}

\author{
Mashallah Valikhani Dehaghani ${ }^{a^{*}}$, Sadjad Tavakkoli ${ }^{\mathrm{b}}$ and Mohammad Malekmohammadi \\ Faradonbeh $^{\mathrm{b}}$
}

${ }^{a}$ Assistant Professor, Department of Governmental Management, Dehaghan Branch, Islamic Azad University, Esfahan, Iran ${ }^{b}$ M.A student, Department of Public Administration, Islamic Azad University, Dehaghan Branch, Esfahan, Iran

C H R O N I C L E

Article history:

Received October 20, 2012

Received in revised format

28 January 2013

Accepted 26 March 2013

Available online

March 272013

Keywords:

Maxwell model

Intellectual capital

ABFA organization

\begin{abstract}
A B S T R A C T
In this paper, we present an empirical investigation to measure the effects of intellectual capital using Maxwell model [Maxwell, J. C. (2003). Thinking for a change: 11 ways highly successful people approach life and work. Faith Words]. The proposed model of this survey designs a questionnaire in Likert scale and distributes it among 64 managers in an Iranian switch organization called ABFA. The main hypothesis of this survey studies whether the managers have beautiful mind in their work or not. There are 11 sub-hypotheses in this survey based on Maxwell model and the results of this survey conclude that "Sharing the ideas" index maintains the highest rate of importance and "being detailed oriented" maintains the lowest rate of importance.
\end{abstract}

\section{Introduction}

Human resources have been considered as the primary source of building successful organizations and successful managers are able to think big and do their best so that their wishes come true (Barker, 1992; Daniels \& New, 1994; Johannessen et al., 2005; Marr, 2008). There are different studies to measure the impact of beautiful mind on performance of organizations (Arenas \& Lavanderos, 2008). Robinson and Kleiner (1996) are believed to be the first who investigated on how to measure an organization's intellectual capital. Soler and de Oro Celestino (2007) performed an investigation for evaluating the scope of intellectual capital in firms' value. Bontis (1998) and Bontis (1999), for instance, proposed a method for measuring intellectual capital within organization in an attempt to compute the performance of different organizations. Bozbura (2004) used this method for measuring intellectual capital in Turkey. El-Bannany (2008) repeated the same process to study of determinants of intellectual capital performance in United Kingdom banks. 
Lim and Dallimore (2004) investigated intellectual capital for service industry. Cornacchione (2010) performed an investigation on human capital by integrating intellectual capital architecture and utility theory. Nazari and Herremans (2007) provided a theoretical discussion designed to push the measurement of intellectual capital into a more rigorous and comprehensive domain. According to Perez and de Pablos (2003) knowledge management literature emphasizes the fact that the achievement of a sustained competitive advantage relies on firm's capacity to develop and to deploy its knowledge-based resources. They argued that not all resources were equally important for the achievement of this competitive edge and proposed an integrative framework to analyze human capital combining with the advances from three various areas of research including knowledge management, intellectual capital, and strategic human resource management. Sudarsanam et al. (2006) performed an investigation on real options and the impact of intellectual capital on corporate value. Finally, Tan et al. (2007) investigated on the relationship between intellectual capital and financial returns of companies.

\section{The proposed study}

In this paper, we present an empirical investigation to study the impact of intellectual capital on management decisions in one of Iranian organization involved with water supply in city of Esfahan, Iran, called ABFA. The study uses Maxwell model (Maxwell, 2003) to perform this investigation and considers the following main hypothesis,

Main hypothesis: Managers of ABFA organization have beautiful mind.

To test the main hypothesis of this survey, we examine the following eleven hypotheses based on Maxwell model,

1. The managers of ABFA organization have macro-vision in their mind

2. The managers of ABFA organization have focused mind.

3. The managers of ABFA organization have creative mind.

4. The managers of ABFA organization have realistic mind.

5. The managers of ABFA organization have strategic mind.

6. The managers of ABFA organization think about possibility of their decisions.

7. The managers of ABFA organization have detailed oriented mind.

8. The managers of ABFA organization have suspicious mind on common thoughts.

9. The managers of ABFA organization share their thoughts with others.

10. The managers of ABFA organization are thinking to make change.

11. The managers of ABFA organization always think about the outcome of their decision.

There are 45 questions associated with the proposed study of this survey in Likert scale from one (Completely disagree) to five (Completely agree) and to test the hypotheses of the survey we use the following hypothesis,

$\begin{cases}H_{0}: & \mu \leq 3 \\ H_{1}: & \mu>3\end{cases}$

The study uses t-student test to verify the hypotheses and the null hypothesis assumes that managers do not have the mentioned feature. 


\section{The results}

In this section, we present details of our survey on testing various hypotheses of this survey. Table 1 demonstrates the results of our survey on testing eleven hypotheses.

\section{Table 1}

The result t-student on the first hypothesis of the survey

\begin{tabular}{llccc}
\hline Hypothesis & Variable & t-student & df & Sig. \\
\hline 1 & Having macro-vision & 18.112 & 64 & 0.000 \\
2 & Having focused mind & 13.117 & 64 & 0.000 \\
3 & Having creative mind & 14.672 & 64 & 0.000 \\
4 & Having realistic mind & 10.856 & 64 & 0.000 \\
5 & Having strategic mind & 9.474 & 64 & 0.000 \\
6 & Having practical mind & 13.492 & 64 & 0.000 \\
7 & Having detailed oriented mind & 6.248 & 64 & 0.000 \\
8 & Suspicious on common mind & 10.360 & 64 & 0.000 \\
9 & Sharing the ideas & 17.848 & 64 & 0.000 \\
10 & Intending to make changes & 16.881 & 64 & 0.000 \\
11 & Thinking about the outcomes of their decisions & 16.881 & 64 & 0.000 \\
\hline
\end{tabular}

As we can observe from the results of Table 1, the null hypotheses for all eleven hypotheses of this survey are rejected when the level of significance is five percent and we can conclude that according to survey, managers of the firm consider macro-vision decisions and they are focused on what they think. They have creative, realistic, strategic and practical minds. In addition, they are highly detailed oriented and suspicious on what the others think, shares their ideas, always try to make changes and think about the outcome of their decisions. Therefore, we can conclude that the main hypothesis of this survey has been confirmed and they have beautiful mind. The important point is to learn more about the relative importance of the components of the survey and Freedman test is used to rank all hypotheses of this survey summarized in Table 2 as follows,

\section{Table 2}

The results of Freedman test

\begin{tabular}{llcc}
\hline \multicolumn{1}{c}{ Hypothesis } & Variable & Freedman & Sig. \\
\hline 1 & Having macro-vision & 6.99 & 0.000 \\
2 & Having focused mind & 6.09 & 0.000 \\
3 & Having creative mind & 7.08 & 0.000 \\
4 & Having realistic mind & 5.19 & 0.000 \\
5 & Having strategic mind & 4.30 & 0.000 \\
6 & Having practical mind & 5.81 & 111.207 \\
7 & Having detailed oriented mind & 3.95 & 0.000 \\
8 & Suspicious on common mind & 4.14 & 0.000 \\
9 & Sharing the ideas & 8.30 & 0.000 \\
10 & Intending to make changes & 7.42 & 0.000 \\
11 & Thinking about the outcomes of their decisions & 6.72 & 0.000 \\
\hline
\end{tabular}

As we can observe from the results of Table 2, "sharing the ideas" maintains the highest rank followed by "intend to make changes", "having creative mind", "having macro-vision". In addition, "being detailed oriented” maintains the lowest rate of importance followed by "strategic mind". 


\section{Conclusion}

In this paper, we have presented an empirical investigation to study the effects of intellectual capital in one of switch firms in Iran. The proposed study of this paper has designed a questionnaire consists of 45 questions based on Maxwell's eleven factors and distributed it among all management teams of this firm. We have analyzed all the data using t-student and the results have confirmed that all components are within acceptable limits and management team was close to have beautiful mind. The moral story was that "sharing the ideas" maintained the highest rank followed by "intend to make changes", "having creative mind", "having macro-vision". In addition, "being detailed oriented" maintained the lowest rate of importance followed by "strategic mind".

\section{Acknowledgment}

The authors would like to thank the management team of ABFA for cordially cooperating in accomplishment of this survey.

\section{References}

Arenas, T., \& Lavanderos, L. (2008). Intellectual capital: object or process?. Journal of Intellectual Capital, 9(1), 77-85.

Barker, J. A. (1992). Future edge: Discovering the new paradigms of success. W. Morrow.

Bontis, N. (1998). Intellectual capital: an exploratory study that develops measures and models. Management decision, 36(2), 63-76.

Bontis, N. (1999). Managing organisational knowledge by diagnosing intellectual capital: framing and advancing the state of the field. International Journal of technology management, 18(5), 433-462.

Bozbura, F. T. (2004). Measurement and application of intellectual capital in Turkey. Learning Organization, 11(4/5), 357-367.

El-Bannany, M. (2008). A study of determinants of intellectual capital performance in banks: the UK case. Journal of Intellectual Capital, 9(3), 487-498.

Cornacchione Jr, E. B. (2010). Investing in human capital: Integrating intellectual capital architecture and utility theory. The Journal of Human Resource and Adult Learning, 6(1), 29-40.

Daniels, A. C., \& New, A. (1994). Bringing out the best in people. New York.

Johannessen, J. A., Olsen, B., \& Olaisen, J. (2005). Intellectual capital as a holistic management philosophy: a theoretical perspective. International Journal of Information Management, 25(2), 151-171.

Lim, L. L., \& Dallimore, P. (2004). Intellectual capital: management attitudes in service industries. Journal of Intellectual Capital, 5(1), 181-194.

Marr, B. (2008). Impacting Future Value: How to Manage your Intellectual Capital. CMA Canada.

Maxwell, J. C. (1993). Developing the leader within you. Thomas Nelson Inc.

Maxwell, J. C. (2003). Thinking for a change: 11 ways highly successful people approach life and work. FaithWords.

Nazari, J. A., \& Herremans, I. M. (2007). Extended VAIC model: measuring intellectual capital components. Journal of Intellectual Capital, 8(4), 595-609.

Perez, J. R., \& de Pablos, P. O. (2003). Knowledge management and organizational competitiveness: a framework for human capital analysis. Journal of Knowledge Management, 7(3), 82-91.

Robinson, G., \& Kleiner, B. H. (1996). How to measure an organization's intellectual capital. Managerial Auditing Journal, 11(8), 36-39.

Soler, L. E. V., \& de Oro Celestino, D. J. C. (2007). Evaluating the scope of IC in firms' value. Journal of intellectual capital, 8(3), 470-493.

Sudarsanam, S., Sorwar, G., \& Marr, B. (2006). Real options and the impact of intellectual capital on corporate value. Journal of intellectual capital, 7(3), 291-308.

Tan, H. P., Plowman, D., \& Hancock, P. (2007). Intellectual capital and financial returns of companies. Journal of Intellectual capital, 8(1), 76-95. 